\title{
Incidence of congenital syphilis according to inequalities and living conditions in the city of Recife, Pernambuco, Brazil
}

\author{
Roberta de Souza Pereira da Silva Ramos 1 \\ iD https://orcid.org/0000-0001-7121-4995 \\ Gledsângela Ribeiro Carneiro 2 \\ iD https://orcid.org/0000-0002-3532-8888 \\ André Luiz Sá de Oliveira 3 \\ iD https://orcid.org/0000-0002-2483-550X \\ Tarcisio Neves da Cunha 4 \\ (iD) https://orcid.org/0000-0001-9832-3825 \\ Vânia Pinheiro Ramos 5 \\ (iD https://orcid.org/0000-0002-4559-934X
}

1,2,5 Programa de Pós-Graduação em Enfermagem. Departamento de Enfermagem. Universidade Federal de Pernambuco. Av. Prof. Moraes Rego. Cidade Universitária. Recife, PE, Brasil. CEP: 50.670-420. E-mail: roberta_sps@hotmail.com

3 Núcleo de Estatística e Geoprocessamento / Centro de Pesquisas Aggeu Magalhães. Fundação Oswaldo Cruz. Recife, PE, Brasil.

4 Centro de Estudos da Saúde do Trabalhador e Ecologia Humana. Fundação Oswaldo Cruz. Rio de Janeiro, RJ, Brasil.

\begin{abstract}
Objectives: to analyze the variation in the incidence rates of congenital syphilis according to the spatial distribution of Life Condition Index (LCI) among neighborhoods in the city of Recife-PE.

Methods: an ecological study, developed from 3,234 cases of congenital syphilis notified in the Sistema de Informação de Agravos de Notificação (Severe Disease Notification Information System), between 2007 and 2016. LCI was built from seven variables related to the dimensions of the environment, education and income, aggregated at the neighborhood levels and spatially distributed in four strata: very high, high, low and very low. The correlation between the rates of congenital syphilis in the strata and LCI was investigated by applying the Spearman correlation coefficient and demonstrated by means of scatter graphics.

Results: the mean rate on disease incidence was 6.8 cases per thousand live births. There was a higher incidence in the strata of very low and low living conditions, as well as in Districts that presented poor sanitary conditions and low schooling for the head of the family (District VII), higher proportion of illiteracy among 10 and 14 year olds (District II) and low income of the head of the household (Districts I, II and VII).

Conclusions: this study showed the persistence of health inequalities in areas with worse living conditions.
\end{abstract}

Key words Congenital syphilis, Social inequity, Geographic mapping

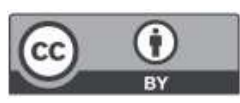




\section{Introduction}

Congenital syphilis is the result of hematogenous dissemination of Treponema pallidum, from infected pregnant women who are not treated or inadequately treated, transmit to their fetus via the placental route. ${ }^{1}$ In untreated women, the infection rate by vertical transmission varies between $70 \%$ and $100 \%$, which makes congenital syphilis a serious public health problem in many parts of the world due to adverse physical, sensory, and developmental events that can be assigned to it. 1,2

Vertical transmission of the disease can occur at any stage of the pregnancy. The main factors that determine its probability are the stage of syphilis in the mother and the duration of exposure of the fetus to the infection in the mother's uterus, which points to the importance of early adequate treatment. The occurrence of congenital syphilis is a sentinel event in the quality of prenatal care provided 3 and the adequacy of the treatment of maternal syphilis, as well as the performance of routinely laboratorial tests and compliance with the recommended basic procedures, prescriptions, and guidelines during consultations, are factors that significantly contribute to the incidence of the congenital form of the infection. 4

In the city of Recife, a survey conducted in the public hospital network revealed that although most users had seven or more prenatal consultations, the puerperal women showed dissatisfaction with the care provided, 5 which may reflect the low adherence to practices recommended by health professionals, and, consequently, increase the risk of vertical transmission of syphilis during pregnancy. As for the quality of prenatal care, the population's living conditions can be a factor associated with difficult access or non-adherence to prescribed treatments, especially in cases of maternal syphilis in which there is a need for treatment, also from the partnership to be considered appropriate.

The influence of living conditions on health status is the subject of studies around the world. ${ }^{6}$ The study of living conditions can be carried out using the synthetic Life Condition Index (LCI), which captures aspects related to the dimensions of longevity, schooling, income, childhood, and housing. The search for elements that can subside in obtaining indicators of living conditions through geographic mapping allows a reflection on poverty, social inequality, and society's lack of access to healthcare. Thus, this mapping is the first step towards the elaboration of a set of measures to guarantee equal access to services that guarantee better living conditions. 7

LCI is a more suitable index to analyze the city level and is capable of reflecting economic and social development in different groups, thus providing a profile for assessing the quality of life ${ }^{8}$ Therefore, this study aims to analyze the variation in the incidence rates of congenital syphilis according to the spatial distribution of LCI among the neighborhoods in the city in Recife-PE.

\section{Methods}

This is an ecological study, which aims to identify risky regions in relation to the mean of the studied process and the search for factors potentially explaining the differences in the incidence found. ${ }^{9}$ It was developed in the city of Recife, capital in the State of Pernambuco, in the Northeast region of Brazil, whose census population is 1,537.704 inhabitants. The territory of the city is divided by the Secretaria Municipal de Saúde (City Health Department) into eight Sanitary Districts: District I, composed of 11 neighborhoods District 2, consisting of 16 neighborhoods ; District III, consisting of 16 neighborhoods ; District IV, consisting of 12 neighborhoods ; District V, consisting of 16 neighborhoods; District VI, consisting of 5 neighborhoods; District VII, made up of 13 neighborhoods and District VIII, are made up of three neighborhoods ; totaling 94 neighborhoods .

The study population corresponded to all cases of congenital syphilis, notified in the city of Recife, from January 2007 to December 2016, through the Sistema de Informação de Agravos de Notificação (SINAN) (Severe Disease Notification Information System). All cases residing outside the city and those reported in duplicate were excluded from the research. Thus, a total of 3,234 cases were studied.

The choice of variables used to construct LCI was based on a previous study, carried out in the same city, which used indicators representing three dimensions. 10 The basic sanitation dimension was composed of the proportion of the variable in the households with adequate sanitary installation and the proportion of the household with direct garbage collection; schooling dimension, by the percentage of the variables of the head in the household with three years of schooling or less, the proportion of the illiterate population was among 10 to 14 year old and a number of illiterate elderly; and finally, the income dimension was formed by the proportion of the variable of the head of the household with monthly income less than or equal to two minimum 
wages and overcrowding .

Regarding the baseline study, only the variable proportion of permanent private household with water supply through internal plumbing-general network or septic tank was excluded because the city had a coverage of almost $100 \%$ for this variable. For this reason, this study will denominate the synthetic indicator of the Índice de Condição de Vida Adaptado (ICVA) (Adapted Living Condition Index). All variables were captured from the Censo Demográfico 2010 (Demographic Census) and aggregated to the levels in the neighborhoods in Recife.

The construction of LCI took place through the factor analysis methodology, a multivariate technique of interdependence that seeks to synthesize the relationships observed between a set of interrelated variables, seeking to identify common factors. The greatest advantage of this technique is that it allows to simplify or reduce much data, which allows the researcher to create initially unobservable indicators composed of the grouping of variables. 11

To verify the adequacy in the use of the factor analysis, the following steps were taken: analysis on the correlation matrix, verification of the KaiserMeyer-Olkin (KMO) statistic, Bartlett's sphericity test, and the analysis of the anti-image matrix. ${ }^{11}$ The correlation matrix measures the linear association between variables using the Pearson's correlation coefficient. Coefficient values above 0.3 indicate that the use of the factor analysis' technique is likely to be appropriate. Bartlett's test of sphericity assesses the hypothesis of the existence of a significant association between the variables used to compose LCI. 12

Regarding the KMO statistic, it assesses the adequacy of the sample regarding to the degree of partial correlation between the variables. Values for KMO statistics equal to or less than 0.6 indicate that the factor analysis may be inadequate. The antiimage matrix seeks to assess the need to eliminate some variables of the model. It is a matrix obtained by calculating the measure of the sample adequacy or Measure of Sampling Adequacy (MSA) for each variable. 13 The higher the MSA values, the better the use of factor analysis. The number of factors extracted followed the Kaiser criterion, which suggests that only factors with an eigen value above one should be extracted.10 The extracted factor values (factor scores) were estimated by regression and constituted the synthetic indicator of the adapted living conditions.

The ICVA in the city was represented through a thematic map categorized by the quartile method.
The clusters in neighborhoods with similar living conditions were grouped into the same stratum. The color grading system was used so that the stratum that represented the neighborhoods with the lowest ICVA received a stronger shade of color and the stratum of the neighborhoods that present the highest ICVA was not shaded. For each stratum, the incidence rate of congenital syphilis was calculated, obtained by the ratio between the number of notified cases of the disease and the number of live births, during the study period, multiplied by one thousand, in each neighborhood in Recife. 14 Data referring to live births were extracted from the Sistema de Informação sobre Nascidos Vivos (SINASC) (Information System on Live Births).

In order to reduce variability and provide better quality indicators, the incidence rates on congenital syphilis were smoothed by the local empirical Bayesian method. 15 For comparison purposes, the study period was divided into two five-year periods: 2007 to 2011 and 2012 to 2016. In each of the periods, the Sanitary Districts whose neighborhoods had the highest incidence rates of the disease were identified.

The cartographic base of digital grids used in this study is available on the City Hall of Recife website. The reference geodetic system used was the SAD-69, later converted to SIRGAS2000 and the UTM (Universal Transverso de Mercator) (Universal Transverse Mercator) projection system. The City Hall base is available at UTM SAD-69, zone 25 south. The production of the maps was carried out by the Núcleo de Estatística $e$ Geoprocessamento da FIOCRUZ-PE(Geoprocessing Nucleus) The Excel worksheet program was used to clean and organize the database with double verification and calculation of the incidence rates of congenital syphilis in the different strata in the neighborhoods. Rate smoothing was performed using TerraView version 4.2.2. software and the preparation of the maps used QGIS ${ }^{\circledR}$ software version 2.14 .

The hypothesis of normality of the data was tested by applying the Kolmogorov-Smirnov (K-S) test, performed in the SPSS software version 17.0, using statistical significance $(\alpha)$ of $5 \%$. According to the parameters adopted for the test, the distribution of ICVA data was considered non-normal (median $=0.14917$; interquartile interval $=1.0036 ; p$ value $=0.006) .16$ Thus, the investigation regarding the correlation between the indicator of congenital syphilis incidence rate and the ICVA was carried out by applying Spearman's rank correlation coefficient ( $\rho$ or rho), which replaces the original data with 
ordered ranks. 17

The Spearman coefficient interpretation parameter followed by this study pursued the following categorization: values between 0 and 0.3 (or 0 and 0.3 ) meant negligible correlation; between 0.31 and 0.5 (or -0.31 and -0.5 ) represented weak correlations; between 0.51 and 0.7 (or - 0.51 and -0.7) moderate correlations; between 0.71 and 0.9 (or 0.71 and 0.9$)$ strong correlations; and $>0.9$ (or $<$ $0.9)$ indicated very strong correlations. 18

The data used in this study originated from a doctoral thesis approved by the Research Ethics Committee of the Health Sciences Center of the Universidade Federal de Pernambuco, CAAE number: 76498617.10000 .5208 and opinion number $2,449,817$.

\section{Results}

In the city of Recife, between January 2007 and December 2016, 3,234 cases of congenital syphilis were reported. The average rate of infection incidence was 6.8 cases per thousand live births, with an increase of $33 \%$ in the rate of the second five-year period compared to the first. The temporal evolution of the number of cases and the incidence rate of the disease in the ten years studied showed an increasing behavior, especially since 2013 .

To analyze the variation in the incidence rates of congenital syphilis according to the living conditions of the population in Recife, the ICVA was constructed, using the neighborhoods in the city as units of analysis.

In the dimension of basic sanitation, the Sanitary District VII in Recife had the highest percentage of neighborhoods whose homes had inadequate sanitation facilities (62\%), while District I had the lowest percentage of inadequacy $(27.7 \%)$. The proportion of household with direct garbage collection had a mean of $98 \%$ among the neighborhoods. The largest proportion of indirect garbage collection was observed in District VII (4.3\%) and the smallest proportion in District IV (0.6\%).

As for the education dimension, District VII had the highest percentage of the head of the household with three years of schooling or less $(15.4 \%)$, while District VI had the lowest percentage among Districts (11.7\%). The proportion of illiterate household members are among 10 and 14 year olds ranging between 0 and $10.8 \%$ among districts. The highest percentage was found in District II (4.1\%) and the lowest in District III (2.1\%).

Regarding the income dimension, the proportion of the head of the household with monthly income below two minimum wages varied between $10.6 \%$ and $96.8 \%$ among the neighborhoods, being higher in Sanitary District V (77.9\%) followed by Districts VIII (74.4\%), I (74.1\%), VII (73.6\%) and II (72.1\%). Overcrowding was similar in all Districts in the city, being slightly higher in Districts II, V, and VII (3.3 residents per bedroom) compared to Districts VIII (3.2 residents per bedroom) and Districts I, III, IV, and VI (3.1 residents per bedroom).

Table 1 shows the correlation matrix between the variables that made up the ICVA in the city. With the exception of the correlation coefficient found between the variables, overcrowding and direct garbage collection, all values of the Pearson correlation coefficients were above 0.3 , which showed potential use of the technique of the factor analysis of the variables. Positive correlations ranged from 0.253 (between overcrowding and direct garbage collection) and 0.803 (among the heads of the household with monthly income less than or equal to two minimum wages and the number of illiterate elderly people). There was no negative correlation between

Table 1

Correlation matrix between the variables used to build the Índice de Condição de Vida Adaptado (ICVA) (Adapted Living Condition Index) according to neighborhoods. Recife-PE, Brazil.

\begin{tabular}{|c|c|c|c|c|c|c|c|}
\hline Variable & 1 & 2 & 3 & 4 & 5 & 6 & 7 \\
\hline 1 Adequate sanitary installation & 1.00 & & & & & & \\
\hline 2 Direct garbage collection & 0.371 & 1.00 & & & & & \\
\hline 3 Head of the household $\leq 3$ years of schooling & 0.548 & 0.417 & 1.00 & & & & \\
\hline 4 Illiteracy 10 to 14 year olds & 0.462 & 0.438 & 0.792 & 1.00 & & & \\
\hline 5 Number of illiterate elderly people & 0.652 & 0.418 & 0.763 & 0.665 & 1.00 & & \\
\hline 6 Head of the household income $\leq 2$ salaries & 0.706 & 0.356 & 0.789 & 0.660 & 0.803 & 1.00 & \\
\hline 7 Overcrowding & 0.675 & 0.253 & 0.600 & 0.477 & 0.576 & 0.723 & 1.00 \\
\hline
\end{tabular}

Based on IBGE data; 2010. 
the variables.

The Kaiser Meyer-Olkin statistic showed good suitability for the factor analysis $(\mathrm{KMO}=0.877)$ and the Bartlett sphericity test showed evidence of significant correlations with the original variables, rejecting the null hypothesis that the correlation matrix is an identity matrix $\left(x^{2}=454.864 ; d f=21\right.$; $p<0.000)$. The MAS values obtained from the antiimage matrix revealed sampling adequacy and no need to exclude any variable from the model.

Table 2 shows the eigen values of the ICVA components. Following Kaiser's criterion, the ICVA was composed of only one factor, which presented an eigen value of 4.55 and carried $65 \%$ of the variance of the original variables. The extracted factor explained $83.5 \%$ of the head of the family income, $78.6 \%$ number of illiterates, $77.6 \%$ of sanitary adequacy, $72 \%$ of illiteracy among 10 and 14 year olds, $60 \%$ of overcrowding , and $28,7 \%$ of direct garbage collection

The factorial load of all variables was considered significant at the $5 \%$ level, with the largest factorial load relating to the head of the family income equal to or less than two minimum wages $(0,914)$, followed by the proportion of the head of the household with three years of schooling or less $(0.887)$, the number of illiterate elderly (0.881), illiteracy among the age of 10 to 14 years old, adequate sanitary installation $(0.778)$, overcrowding $(0.775)$, and direct garbage collection ( 0.536$)$.

Figure 1 shows the spatial distribution of the ICVA according to the 94 neighborhoods in the city of Recife and the smoothed rates of congenital syphilis in the five-year period 2007-2011 and 20122016.

The ICVA geographic mapping evidenced clear neighborhoods in the districts with a very high ICVA surrounded by neighborhoods classified with intermediate and low ICVA. The Sanitary District III had
$56.2 \%$ of its neighborhoods allocated in the very high ICVA stratum (Casa Forte, Parnamirim, Tamarineira, Graças, Jaqueira, Derby, Espinheiro, Santana, and Aflitos; $40 \%$ of the neighborhoods classified in this stratum in District VI) (Brasília Teimosa and Boa Viagem); in District I, 27.2\% (Boa Vista, Santo Antônio and Soledade); in District IV, 25\% (Cordeiro, Torre, and Zumbi); in District II, 16.6\% (Encruzilhada, Ponto de Parada and Torreão), in District VII, 15.3\% (Mangabeira and Pau-Ferro) and in District V, 6.2\% (Curado).

In relation to the very low ICVA stratum, Sanitary District VII stood out with $46.1 \%$ of its neighborhoods allocated in this stratum (Passarinho, Brejo da Guabiraba, Córrego do Jenipapo, Macaxeira, Nova Descoberta, and Brejo do Beberibe); followed by District I, 36.6\% (Recife, Cabanga, São José, and Ilha Joana Bezerra); Districts II and VIII, both with 33.3\% (Beberibe, Porto da Madeira, Cajueiro, Água Fria, Alto Santa Terezinha, and Bomba do Hemetério) and (Jordão) and, finally, Districts III and V, both with $12,5 \%$ of its neighborhoods with very low ICVA (Apipucos and Sítio dos Pintos) and (Sancho and Totó), respectively.

As for the spatial distribution of smoothed rates of congenital syphilis, the first five-year period revealed concentrations of higher values in the districts belonging to Sanitary District I $(63.3 \% ; n=7$ districts); followed by District VII (53.8\%; $\mathrm{n}=7$ districts), and District II (38.8\%; $\mathrm{n}=7$ districts). Districts IV and V had only one neighborhood allocated in the stratum with the highest concentration of rates $(20 \%$ and $6.2 \%$, respectively), while Districts II, IV, and VIII did not have neighborhoods in this stratum.

In the second five-year period, the districts located in the stratum with the highest concentration of rates were located in Districts VII (69.2\%; $n=9$

Table 2

Eigen values of the Índice de Condição de Vida Adaptado (ICVA) (Adapted Living Condition Index) components. RecifePE, Brazil.

\begin{tabular}{|c|c|c|c|c|c|c|}
\hline \multirow[t]{2}{*}{ Components } & \multicolumn{3}{|c|}{ Initial Eigen value } & \multicolumn{3}{|c|}{ Sums of squared load extraction } \\
\hline & Total & $\%$ variance & $\%$ accumulated & Total & $\%$ variance & $\%$ accumulated \\
\hline 1 & 4,552 & 65,022 & 65,022 & 4,552 & 65,022 & 65,022 \\
\hline 2 & 0.849 & 12,124 & 77,146 & & & \\
\hline 3 & 0.646 & 9,234 & 86.38 & & & \\
\hline 4 & 0.359 & 5,129 & 91,509 & & & \\
\hline 5 & 0.27 & 3,864 & 95,372 & & & \\
\hline 6 & 0.174 & 2,488 & 97.86 & & & \\
\hline 7 & 0.15 & 2.14 & 100 & & & \\
\hline
\end{tabular}


Spatial distribution of the Indice de Condição de Vida Adaptado (ICVA) (Adapted Living Condition Index) in 94 neighborhoods in the city of Recife and the smoothed rates of congenital syphilis, per 100,000 inhabitants, in the fiveyear period 2007 to 2011 and 2012 to 2016.
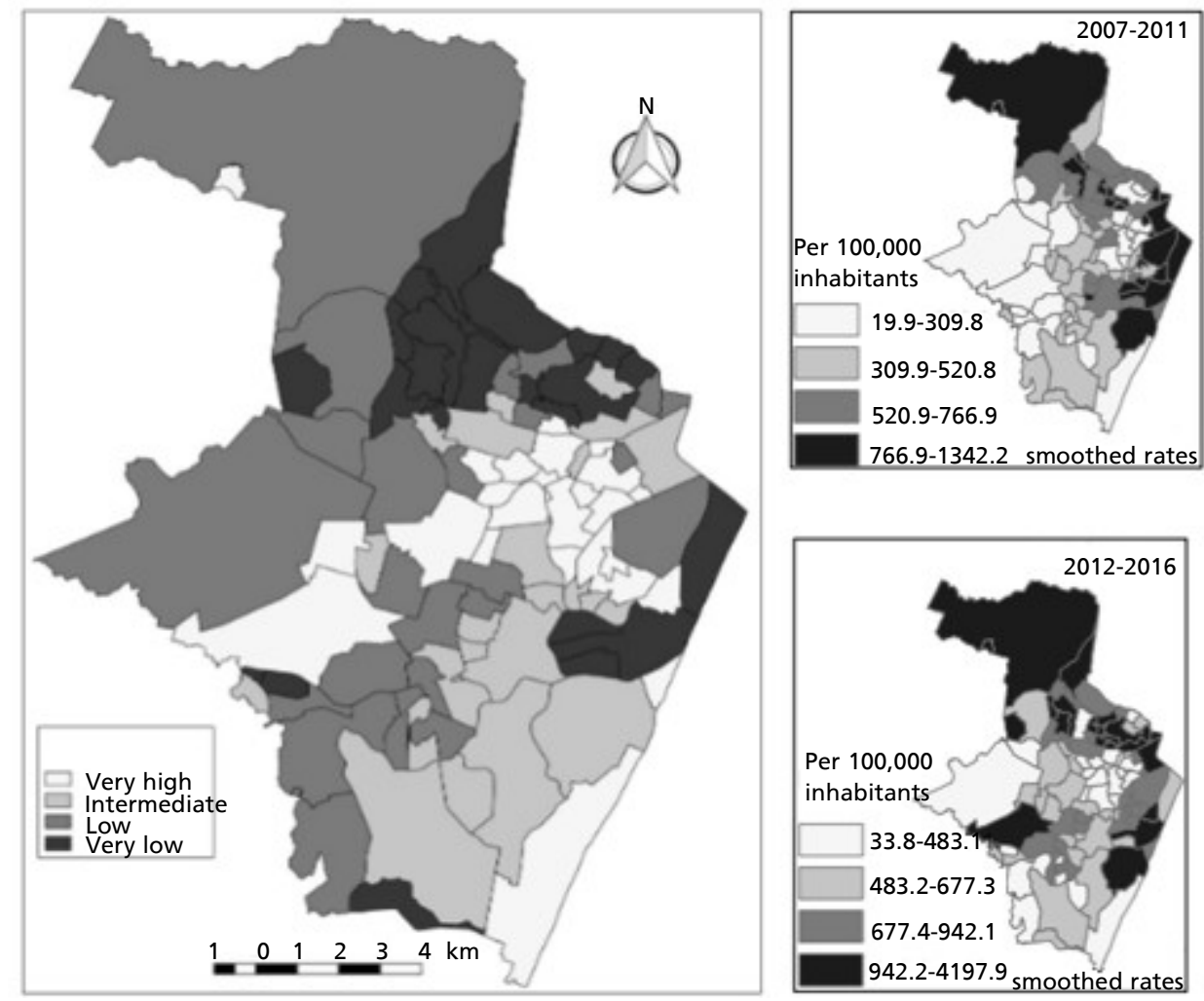

districts) and II (38.8\%; $\mathrm{n}=7$ districts). In Districts VI, V, and III, only one neighborhood was located in the range with the highest rates, which represented a percentage of $20 \%$, and $6.2 \%$ for the last two. In District I, two neighborhoods were in the stratum with the highest rates (18.1\%), and Districts IV and VIII did not reveal neighborhoods in this stratum.

Table 3 shows the smoothed mean rate of incidence of congenital syphilis according to ICVA stratification, in both five-year periods studied. In both periods of the study, the stratum of neighborhoods with the lowest ICVA had the highest incidence coefficients of congenital syphilis, while the lowest rates of infection were observed in the stratum of the neighborhoods with high ICVA, in the first five-year period, and intermediate, in the second five-year period.

In the first five years, the correlation between the incidence rate of congenital syphilis and ICVA was null $(\rho=0.263)$. In the second five-year period, a weak correlation was observed $(\rho=0.385)$. Figure 2 shows the curvilinear behavior of the point cloud in the scatter graphics.

\section{Discussion}

The incidence of congenital syphilis in Recife between 2007 and 2016 was higher than the national (3.9/1000 live births) and regional (4.3/1000 live births) means and similar to the means in Pernambuco $(6.7 / 1000$ live births) $)$ in the same period. 19 The $33 \%$ increase in the disease detection rate in the second five-year period compared to the first may have been influenced by the shortage of penicillin in the market between 2014 and 2016, which reached practically all the Brazilian States20 and by the resistance of some professionals to use the drug indicated due to the risk of anaphylactic reaction, 21 which shows difficulties in the manage- 
Table 3

Distribution of the number of cases of congenital syphilis, live births, and mean rate of infection according to ICVA stratification of the neighborhoods in Recife-PE, Brazil, between 2007 and 2016.

\begin{tabular}{lcccccc}
\hline $\begin{array}{l}\text { Stratification of } \\
\text { ICVA }\end{array}$ & \multicolumn{2}{c}{$\begin{array}{c}\text { Number of congenital } \\
\text { syphilis cases }\end{array}$} & \multicolumn{2}{c}{$\begin{array}{c}\text { Number of live } \\
\text { births }\end{array}$} & & $\begin{array}{c}\text { Mean incidence rate of } \\
\text { congenital syphilis }\end{array}$ \\
\cline { 2 - 7 } & $2007-2011$ & $2012-2016$ & $2007-2011$ & $2012-2016$ & $2007-2011$ & $2012-2016$ \\
\hline Very high & 98 & 232 & 10976 & 7387 & 434.81 & 726.48 \\
Intermediate & 352 & 567 & 17971 & 11688 & 510.01 & 635.08 \\
Low & 333 & 700 & 20788 & 14475 & 585.61 & 794.75 \\
Very low & 315 & 615 & 13916 & 9105 & 813.98 & 888.78 \\
\hline
\end{tabular}

Figure 2

Linear correlations between smoothed mean incidence rates of congenital syphilis and ICVA in the population residing in the city of RecifePE, Brazil, in the five-year period 2007 to 2011 and 2012 to 2016.

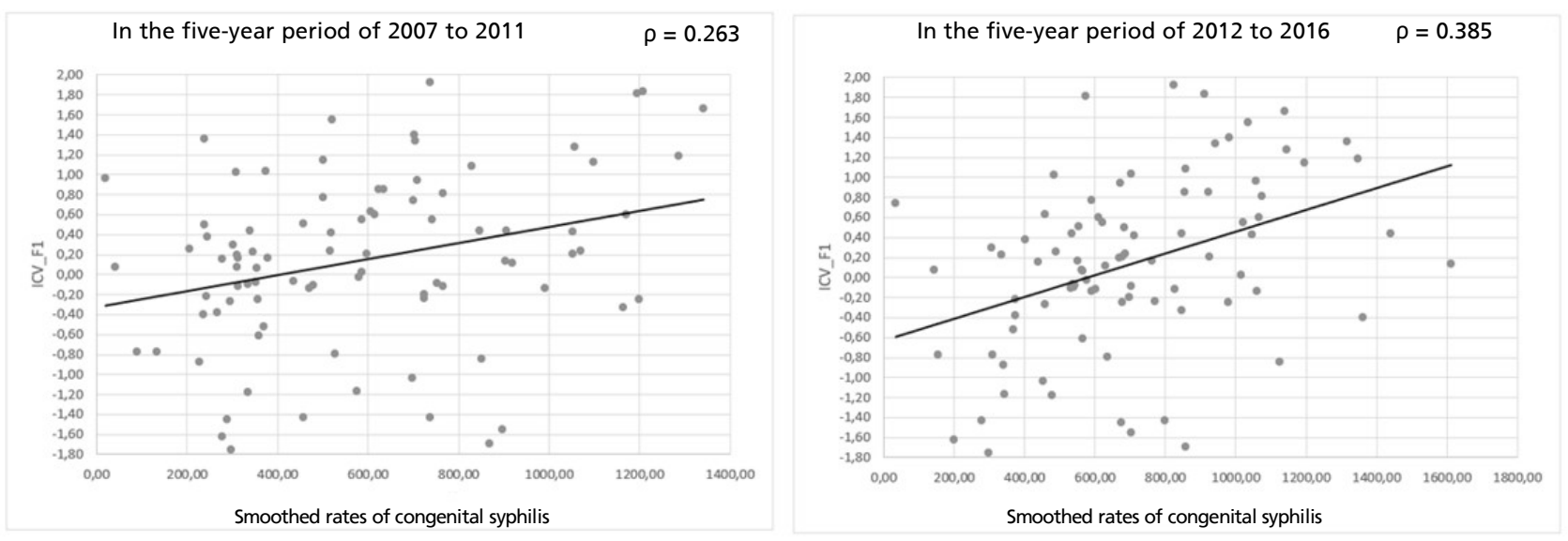

ment of syphilis during pregnancy. 3

To assess whether the variation in the disease incidence rates can be explained by living conditions, this study proposed to use a synthetic indicator capable of reflecting the population's social inequalities and health conditions. Understanding how social inequalities influence the distribution of the diseases in the society represents a challenge for the public health.

The epidemiological paradigm is based on the assumption that the disease is unequally distributed in space and also occurs unequally on subjects as a result of their insertion into the social reproduction system. This idea corroborates the more politicized approach to the study in social and health inequalities, which assumes that the condition of inequality or injustice produced in the social structure is reflected in the health-disease process and is not linked solely to biological and demographic characteristics. 22

The category "living condition" for this study of social inequalities was proposed by Castellanos (1997), who emphasizes that "each individual, family, community and population group, at every moment of their existence, has needs and risks that are characteristic to them, either by individual attributes, by their geographical and ecological location, or by their culture and educational level".23 Thus, the risk of vertical transmission of syphilis can be higher or lower according to the profile of living conditions expressed by the dimensions of social reproduction, which, in this study, were represented by variables related to the population's environment, schooling, and economic structure.

Between the maximum and minimum values, the variables representing the living conditions obtained 
different values, which expressed the heterogeneity of the indicator between the districts. The variation in congenital syphilis incidence coefficients found corroborates the persistence of health inequalities in neighborhoods with the worst living conditions. ${ }^{24}$ Similarly, a previous study carried out in the same city detected an inverse relationship between the living conditions of neighborhood strata and the magnitude of infant mortality by age group and underlying cause, revealing hidden inequalities in the city's average indicators. 10

The incidence coefficient of the infection was higher in the stratum of neighborhoods with very low ICVA and lower in the strata with very high ICVA, in the first five-year period, and intermediate, in the second five-year period. The comparative analysis between the spatial distribution of ICVA among the neighborhoods and the smoothed rates of congenital syphilis incidence revealed that Districts I, II, and VII, which had the highest rates of the disease in the first five years, and District VII, which presented the highest rate of infection in the second five-year period coincided with Districts that obtained the highest percentage of neighborhoods allocated in the very low ICVA stratum.

It should be noted that among the neighborhoods with very low ICVA, there was a stationary nature of the high rates of congenital syphilis in District I (São José neighborhood), II (Alto Santa Terezinha and Bomba do Hemetério neighborhoods), and VII (Nova Descoberta), which corroborates the probable influence of low living conditions on the persistence of high rates of infection.

Inequality in living conditions and its relationship to illness corroborate what the World Health Organization refers to as the social gradient of health, ${ }^{25}$ which means that, within the same territory, the relationship between socioeconomic status and health varies gradually according to the degree of inequities. In this study, this could be evidenced by the identification of a higher incidence of congenital syphilis in the very low and low living conditions strata, as well as in Districts with poor sanitary conditions and low schooling level of the head of the household (District VII), a higher proportion of illiteracy among 10 and 14 year olds (District II) and low income of the head of the household (Districts I, II and VII).

A similar result was highlighted by a study on tuberculosis carried out in the same city, which showed a relationship between the highest incidence of the disease and the poorest areas according to the stratification of the living conditions. 26 The condition of poverty is recognized as one of the determi- nants of the access of pregnant women to inadequate prenatal care, which contributes to the maintenance of high rates of vertical transmission in this population. 27

In this study, the value of congenital syphilis incidence rates in neighborhoods strata proved to be a sensitive indicator to reveal the intra-urban difference in living conditions and suggest low prenatal quality and lack of adherence to health recommendations provided by professionals. The uneven distribution of congenital syphilis among the neighborhoods corroborated the results of a previous survey carried out in the same city between 2004 and 2006.27

An interesting fact, however, was the observation of neighborhoods considered noble, such as Apipucos, allocated in the very low ICVA stratum, as well as others considered to be of high social need, such as Brasília Teimosa, allocated in the high ICVA stratum. This result reflects on the polarization of living conditions among districts in the city, expressed by the existence of social counterpoints and evidenced by the existence of poverty located in rich districts. This socioeconomic heterogeneity among neighborhoods may explain the lack of correlation between the ICVA and the incidence rates of congenital syphilis in the first and second five-year periods. Furthermore, the results suggest that the neighborhoods do not keep similar characteristics over time, which does not allow the identification of regions of sustained high or low susceptibility to the adverse outcome studied.

The study demonstrated the usefulness of the ICVA geographic mapping to explain the differentials risks of congenital syphilis incidence according to the indicator and to identify priority areas for interventions to control the vertical transmission of the disease, but it leaves as a suggestion to carry out other researches that investigate the correlation between the risk of vertical transmission of syphilis and other synthetic indicators related to the process of social health determinants.

Despite of having limitations regarding to data quality, typical of studies with databases, the results of this research showed that the Sanitary Districts that had higher incidence rates of congenital syphilis coincided with the strata of neighborhoods with very low and low living conditions, showing the persistence of health inequalities in areas with the worst living conditions. Districts I, II, and VII of Recife were identified as priority areas for public health interventions aimed in preventing vertical transmission of syphilis and its adverse outcomes. 


\section{Authors' contribution}

Ramos RSPS: Research design, data collection, analysis and discussion of results, and article writing. Carneiro GR: Data collection, analysis and discussion of results. Oliveira ALS: Preparation of maps and analysis of results. Cunha TN: analysis and discussion of results. Ramos VP: analysis of results, grammar correction and review of the final draft of the manuscript. All authors approved the final version of the article.

\section{References}

1. Brasil. Ministério da Saúde. Secretaria de Vigilância em Saúde. Programa Nacional de DST/AIDS. Diretrizes para controle da sífilis congênita: manual de bolso / Ministério da Saúde, Secretaria de Vigilância em Saúde, Programa Nacional de DST/Aids. 2 ed. Brasília, DF; 2006.72 p. il. (Série Manuais 24).

2. Bulletin of the World Health Organization [homepage da internet]. Estimativas globais e regionais da prevalência e incidência de quatro infecções sexualmente transmissíveis curáveis em 2016. Disponível em: https:/www.who.int/bulletin/online_first/en/

3. Domingues RMSM, Saraceni V, Hartz ZMA, Leal MC Sífilis congênita: evento sentinela da qualidade da assistência pré-natal. Rev Saúde Pública. 2013; 47 (1): $147-$ 57.

4. Nunes JT, Gomes KRO, Rodrigues MTP, Mascarenhas MDM. Qualidade da assistência pré-natal no Brasil: revisão de artigos publicados de 2005 a 2015. Cad Saúde Coletiva. 2016; 24 (2): 252-61.

5. Silva ALA, Mendes ACG, Miranda GMD, Souza WV. A qualidade do atendimento ao parto na rede pública hospitalar em uma capital brasileira: a satisfação das gestantes. Cad Saúde Pública. 2017; 33 (12): e00175116.

6. Silva VL, Leal MCC, Marino JG, Marques APO. Associação entre carência social e causas de morte entre idosos residentes no Município de Recife, Pernambuco, Brasil. Cad Saúde Pública. 2008; 24(5): 1013-23.

7. Antunes FP. Desigualdades sociais na distribuição espacial das hospitalizações por doenças respiratórias. Cad Saúde Pública. 2013; 29 (7): 1346-56

8. Programa das Nações Unidas para o Desenvolvimento. Desenvolvimento humano e IDH. Brasília: PNUD, 2016 [internet]. [acesso abr 13 2020]. Disponível em: http://www.pnud.org.br/IDH/DH.aspx?indiceAccordion=0;

9. Carvalho MS, Souza-Santos R. Análise de dados espaciais em saúde pública: métodos, problemas, perspectivas. Cad Saúde Pública. 2005; 21 (2): 361-78.

10. Gimarães MJB, Marques NM, Filho DAM, Szwarcwald CL. Condição de vida e mortalidade infantil: diferenciais intra-urbanos no Recife, Pernambuco, Brasil. Cad Saúde Pública. 2003; 19 (5): 1413-24.

11. Reis E. Análise Fatorial. In: Favero LP, Belfiore P, Silva
FL, Chan BL. Análise dos dados: modelagem multivariada para tomada de decisões. Rio de Janeiro: Campus; 2009. p. 235-65.

12. Pestana M, Gagueiro J. Análise de dados para ciências sociais: a complementaridade do SPSS. 4 ed. Lisboa: Edições Silabo; 2005;

13. Hair JF, Anderson RE, Tatham RL, Black WC. Análise multivariada de dados. 5 ed. Porto Alegre: Bookman; 2005. 593 p. il;

14. Rede Interagencial de Informações para a saúde (RIPSA). Indicadores Básicos para saúde no Brasil: conceitos e aplicações / Rede Interagencial de informações para a SaúdeRipsa. 2 ed. Brasília: Organização Pan-Americana da Saúde; 2008. 349 p.

15. Dos Santos, Alexandre E, Rodrigues AL, Lopes DL. Aplicações de Estimadores Bayesianos Empíricos para Análise Espacial de Taxas de Mortalidade. In: GeoInfo. 2005. p. 300-9.

16. Lopes MM, Castelo Branco VTF, Soares JB. Utilização dos testes estatísticos de Kolmogorov-Smirnov e Shapiro-Wilk para verificação da normalidade para materiais de pavimentação. Transportes. 2013; 21 (1): 59-66.

17. Norman GR, Streiner DL. Biostatistics. The bare essentials. 4 ed. Shelton: People's Medical Publishing House; 2014;

18. Mukaka MM. Statistics corner: A guide to appropriate use of correlation coefficient in medical research. Malawi Med J. 2012; 24 (3): 69-71.

19. Brasil. Ministério da Saúde. Secretaria de Vigilância em Saúde. Departamento de DST, Aids e Hepatites Virais. Bol Epidemiol. Sífilis. 2019; 49 (45). Brasília,DF; 2019.

20. Centers for Disease Control and Prevention (CDC). Sexually transmitted diseases treatment guidelines. MMWR, 64 (RR-03), p. 43-45; 2015. Disponível em: http://www.cdc.gov/std/tg2015/syphilis-pregnancy.htm. [acesso 1 set. 2016]. MEDSCAPE. Desabastecimento de penicilina alerta para desafio global de combate à sífilis. [acesso 2 abr. 2017]. Disponível em http://portugues.medscape.com/verartigo/6500488.

21. Guanabara MAO, Leite-Araújo MA, Matsue RY, Barros VL, Oliveira FA. Acesso de gestantes às tecnologias para prevenção e controle da sífilis congênita em FortalezaCeará, Brasil. Rev Salud Pública. 2017; 19 (1): 73-8. 
22. Saúde, doença e condições de vida [editorial]. REME - Rev Min Enferm. 2006; 10 (2): 105.

23. Castellanos PL. Epidemiologia, Saúde Pública, Situação de Saúde e Condições de Vida. Considerações Conceituais. In: Barata RB. Condições de vida e situação em saúde. Rio de Janeiro: Abrasco; 1997. cap.2, p. 31-75.

24. Carvalho LAS, Santos VS, Melo CM, Gurgel RQ, Oliveira CCC. Desigualdades em saúde: condições de vida e mortalidade infantil em região do nordeste do Brasil. Rev Saúde Pública. 2015; 49: 5.

25. World Health Organization. Closing the Gap: Policy into Practice on Social Determinants of Health: Discussion Paper [Internet]; 2011. [acesso 3 mai 2011]. Disponível em: http://www.who.int/sdhconference/discussion_paper/en/
26. Hino P, Villa TCS, Cunha TN, Santos CB. Padrões espaciais da Tuberculose e sua associação à condição de vida no município de Ribeirão Preto. Ciênc Saúde Coletiva. 2011; 16 (12): 4795-4802.

27. Melo NGDO, Filho DAM, Ferreira LOC. Diferenciais intraurbanos de sífilis congênita no Recife, Pernambuco, Brasil (2004-2006). Epidemiol Serv Saúde. 2011; 20 (2): $213-22$

Received on September 22, 2020

Final version presented on May 14, 2021

Approved on June 17, 2021 